Open Access

\title{
The level of decentralization and property rights protection--a sociological analysis of property rights
}

\author{
Zhenghan $\mathrm{CaO}^{1}$ and Guoqiang Feng ${ }^{2^{*}}$
}

* Correspondence:
fenggq@|zu.edu.cn
${ }^{2}$ School of Economics, Lanzhou
University, No.222 Tianshui Road,
Lanzhou 730000, Gansu Province,
China
Full list of author information is
available at the end of the article

available at the end of the article

\begin{abstract}
Economists have used the mechanism of interjurisdictional competition to explain how decentralization affects the degree of property rights protection. This fails however to account for another significant question: In China, can the local decentralization from the provincial level to the prefectural (county) level be more effective in protecting the private property rights of investors, especially when goods and production factors cannot flow freely among regions? The social perspective of property rights can help answer this question. In this study, we find that within the governance structure of decentralization, the mechanism of vertical constraints is more significant than the mechanism of interjurisdictional competition in protecting the private property rights of investors. However, the effectiveness of the vertical constraints mechanism depends on the resistance costs of discontented investors. Decentralizing to the prefectural level, in comparison to the provincial level, lowers these resistance costs for investors while strengthening the mechanism of vertical constraints, thereby improving the degree of property rights protection for private investors.
\end{abstract}

Keywords: Property rights, Level of decentralization, Resistance cost, Vertical constraints, Interjurisdictional competition

\section{Introduction}

Property rights cannot be defined simply in terms of law or external rules, since they are socially constructed (Zhang 2003, 2005; Zhe and Chen 2004, 2005; Shen and Wang 2005; Liu 2003a; Cao 2008). Using the language of game theory, property rights is the outcome when the players have reached a game equilibrium (Sugden 1989). The outcome of game equilibrium is a social construction and in addition to the law, which is only one influential element, includes other aspects such as the "widely accepted principle of fairness," as well as the "impact" caused by interested parties, such as the number of people involved, the intensity of the appeal, and the level of violence. Sociologists have named these arguments of property rights protection as the "social perspective of property rights" (Cao 2008). ${ }^{1}$ Clearly, in the process of socially constructing property rights, the government plays an important role, yet sociologists have neglected the question whether the way in which the government's authority is organized and how it operates can influence the social construction outcome of property

(c) The Author(s). 2017 Open Access This article is distributed under the terms of the Creative Commons Attribution 4.0 International License (http://creativecommons.org/licenses/by/4.0/), which permits unrestricted use, distribution, and reproduction in any medium, provided you give appropriate credit to the original author(s) and the source, provide a link to the Creative Commons license, and indicate if changes were made. 
rights. This paper is an academic endeavor to promote the approach of "the social perspective of property rights."

In this article, the way in which the government's authority is organized and how it operates refers to the allocation of administrative authority between the different levels of government, which is known as the "level of decentralization." We will, therefore, discuss in the following text whether the level of decentralization can influence the social construction outcome of property rights protection. This argument, which can be traced back to research in economics, says that decentralization contributes not only to the restrictions in government behavior but also contributes to the protection of private property rights (Montinola et al. 1995; Qian and Weingast 1997; Blanchard and Shleifer 2001; Landry 2008; Xu 2011). Economists have primarily used the theory of interjurisdictional competition to explain this point of view. The theory emphasizes that after authority has been decentralized to a local level, the central government can introduce a competition mechanism between regions. This will lead local government officials to compete with each other for regional economic development and political promotion, thereby restricting the behavior of local government officials and encouraging local government officials to protect investors' property right (Montinola et al. 1995; Qian and Weingast 1997; Maskin et al. 2000; Zhou 2008; Xu 2011).

Nevertheless, the theory of interjurisdictional competition has neglected the fact that property rights are products of social construction. For example, it has overlooked the possibility that investors might fight in an effort to protect their property rights; it has also ignored the possibility that investors could pressure the local government through collective resistance and protests and would then be more likely to exert political pressure on the local government. For this reason, interjurisdictional competition theory cannot fully explain whether the level of decentralization can affect the degree of property rights protection in countries with multiple levels of local government. In other words, does allocating administrative authority to a lower level of government lead to more effective property rights protection for private businesses? To answer this question from the perspective of interjurisdictional competition theory, if the production factors can flow freely, the answer would be positive. For investors whose goods and production factors can flow freely among regions, the lower the level that the administrative authority is allocated to and the smaller the actual jurisdictional authority of local governments, the easier it is for the interjurisdictional flow of production factors, and therefore the more beneficial the interjurisdictional competition is. However, such inferences are questionable as they presume that production factors can flow freely between jurisdictions, which in many cases is not plausible, and therefore there is doubt about the reliability of this hypothesis. ${ }^{2}$

Economists' arguments have not elaborated much on the question of whether the level of decentralization can influence the degree of the property rights protection, especially when goods and production factors cannot flow freely among regions. The "social perspective of property rights" can contribute to answering the questions. We will demonstrate that, under normal conditions, even though some key production factors such as land, mineral resources, buildings, infrastructure, etc. cannot flow freely between jurisdictions, the answer to the above question is still a positive one. The reason is that in industries where the factors of production cannot move freely among regions, investors can avail themselves of the vertical constraints mechanism in order to protect 
their property rights. Whether or not this type of mechanism is effective depends on the size of the cost investors incur when they express demands, initiate protests, or organize appeals (any method by which they try to protect their legal rights). This set of costs will be called the "resistance costs." We will demonstrate that in China, when comparing with decentralizing to the provincial level, decentralizing to the prefectural level can lower resistance costs for investors, making the mechanism of vertical constraints even more efficient, therefore improving the degree of property rights protection for private businesses. ${ }^{3}$

The rest of the article is organized as follows. Firstly, a competition model of multilevel government is developed in order to formalize our argument; from this, a hypothesis is put forward. In the "Mergers and reorganizations of China's coal industry (2008-2013): a comparison of the degree of property rights protection between provinces" section, an empirical analysis is conducted to prove the hypothesis put forward in the previous section. The empirical analysis focuses on the degree of property rights protection within Chinese provinces of major coal production enterprises during coal mine industry "mergers and reorganizations" that occured from 2008 to 2013. During the mergers and reorganizations of this period, we find systemic differences among provinces regarding the degree of property rights protection that privately run coal mine enterprises experienced. The "Level of decentralization and degree of property rights protection: correlation analysis" and "Hypothesis test" sections will discuss the causes of such differences and its mechanism, which supports our theoretical hypothesis. Finally, we conclude and further discuss the findings.

\section{Model and hypothesis}

The model described below is derived from Blanchard and Shleifer's yardstick competition model (Blanchard and Andrew Shleifer 2001). Based on their benchmark model, we introduce the theory of multi-level government competing for regional economic growth or opportunities for political promotion. We intend to use this theory to theoretically deduce how the level of decentralization affects the degree of private property rights protection. From the decentralization of the governance structure, apart from interjurisdictional competition, there exists another property rights protection mechanism, the "vertical constraints mechanism." We aim to show the relationship between level of decentralization and the mechanism of vertical constraints.

\section{The mechanism of vertical constraints}

The "mechanism of vertical constraints" is endogenous in the governance structure of political centralization and administrative decentralization. This type of governance structure refers to the fact that the central government has primary authority in managing the selection, appointment, dismissal, and evaluation of government officials, and administrative authority is therefore allocated to the local government so that they can directly govern enterprises and citizens. This governance structure is called "central government governing the officials and the local government governing the citizens" (Cao 2011). Within this structure, the local government is responsible for protecting the rights of investors, and accordingly, the local government faces restrictions from both the top and the bottom: One is a top-down constraint due to its supervision by 
the central government. If local officials abuse their authority, they may face intervention by the central government and may even be punished; the other is a bottom-up constraint exercised by investors, if their private property rights are violated by the local government, investors are likely to protest against the local government and may even lodge complaints with the central government. Under certain conditions, this type of two-way restriction may constrain the behavior of the local government when it comes to property rights violations, thereby promoting their role in protecting private investors' property rights.

Of course, the mechanism of vertical constraints is by no means an argument against the mechanism of interjurisdictional competition. Under the conditions where the mechanism of interjurisdictional competition is effective, investors can threaten to withdraw investment when their rights are being violated by the local government. This would increase the effectiveness of protests and complaints by investors, which in turn would strengthen the effectiveness of the vertical constraints mechanism. Despite this, the mechanism of vertical constraints still bears significance on its own.

Firstly, in comparison with the mechanism of interjurisdictional competition, the vertical constraints mechanism relies on a different set of preconditions. The mechanism of interjurisdictional competition is dependent on goods and production factors being able to flow freely among regions. This is not a necessary condition for the vertical constraints mechanism; rather it depends on the central government's ability to intervene in relation to local government's behavior. This is done through supervision, rewards and punishments, along with the ability of investors to resist, through for example, initiating protests or complaints and appeals, any corrupt behavior that the local government may display against their property rights. Consequently, in industries where it could be difficult to employ the mechanism of interjurisdictional competition, the vertical constraints mechanism would be of great importance.

Secondly, the effectiveness of these two mechanisms relate quite differently to the level of decentralization. For the mechanism of interjurisdictional competition, the preconditions for it to take effect are rarely related to the level of decentralization. This is because, if a business needs factors of production that are immovable, then, regardless of which level of decentralization is reached, this specific characteristic of the production factor still will not change. However, for the vertical constraints mechanism, the preconditions for it to take effect is in fact closely related to the level of decentralization. We will prove that decentralizing to prefectural level compared to provincial level can effectively reduce the resistance costs for investors, improve their ability to protest and appeal, and cause the vertical constraint mechanism to come into effect more easily.

\section{A mathematical model}

Blanchard and Andrew Shleifer (2001) once demonstrated, using a mathematical model, that if local decentralization were to take on the role of property rights protection, a prerequisite had to be added. That is, the central government would have to have the ability to both give incentives to and punish local officials. In their model, local officials face two choices: to protect property rights, thereby encouraging investment and stimulating economic growth, or to extract rents from investors with the 
intention of benefiting themselves privately (denoted by $b$ ). This would of course directly affect incentives for private investment and, thus, inhibit economic growth. Regardless of how local officials made their choice, the results would be reflected in the regional net outputs, denoted by $y$ (which can also be interpreted as additional regional tax revenues). In order to control the behavior of the local government officials, the central government has two means of control: (1) tax dividends and (2) political rewards and punishments. Tax dividends represent the fact that the local government is allowed to share in the additional regional net output $(y)$; the proportion being shared is denoted by $a$ ( $a$ is determined by the central government), where ay is the amount shared by local government officials. Political rewards and punishments influence the political career of the local government official:

i. If a local government official decides to extract rents (kill growth), he has probability $p$ of remaining in office (in other words, the probability that the central government replaces him is $1-p$ );

ii. If, however, the local government official decides to protect the property rights of businesses (foster growth), in effect stimulating economic growth, he has probability $q$ of retaining his position in office.

Therefore, $q$ reflects how strongly motivated local government officials are by the central government through the use of performance results; we shall call this performance-based motivation. The larger $q$ is, the more strongly motivated the local government officials are to stimulate economic growth; $1-p$ reflects the intensity of punishment local officials experience when the central government punishes based on performance results. The larger $1-p$ (i.e., the smaller $p$ is), the more intense the punishment is for the local government official. The central government can affect both probabilities for the local government, regardless of why he stays in power, whether to enjoy revenues from growth or to enjoy private benefits from extraction. If $q \geq p b / a y$, the local government chooses to foster growth by protecting property rights; otherwise, it chooses to kill growth by extracting rents (Blanchard and Andrew Shleifer 2001).

Blanchard and Shleifer's model of yardstick competition should be revised for its limitations. That is, only two levels of government are considered, the central government and the local government. The local government contains at least two levels: provincial government and prefectural government. Additionally, their model does not consider the constraining effects that investors' resistance could have on local officials. Hence, their model cannot fully consider the vertical constraints mechanism and so, we should make two revisions to their model.

Firstly, we have introduced private investors into the model, which may directly constrain the choice of the local government. If the local government decides to violate the property rights of business owners, then it might instigate protests and appeals from private investors. However, how effectively private investors can initiate actions of resistance, through protest or appeal, as well as endure any other necessary costs for related actions to be taken (i.e., resistance costs) is denoted by $c .{ }^{4}$ Now, if the local government official decides to adopt a rent extracting behavior, his probability of remaining in office $p$ is then a function of investors' resistance costs $(c)$, denoted by $p(c)$. 
Secondly, we revise the setup of the local government described in Blanchard and Shleifer's model by introducing two levels of local government: provincial government and prefectural (county) government. This adds the assumption that the central government directly controls the provincial government, and that the provincial government directly controls the prefectural (county) government. After this revision, decentralization then has two different levels. The first is that the central government directly decentralizes its authority to the provincial government, but the provincial government does not decentralize any authority to the prefectural (county) government. In this case, any level of government below the provincial level implements a vertical governance structure. We call this "decentralization to the provincial level." The second is "decentralization to the prefectural (county) level". This is when the provincial government is empowered with authority from the central government, and further decentralizes authority to the prefectural (county) government.

After the above revisions, we can begin discussing the relationship between the level of decentralization and the degree of property rights protection.

First, if decentralization is only to the provincial level, then the provincial government has the right to directly supervise and regulate enterprises and citizens. Investors face the possibility of responding to provincial level government officials who violate their rights, so the object of resistance in this case is the provincial government. Assume that investors must face the provincial government in protest and appeals; the resistance cost is then $c_{1}$. The provincial government chooses to foster growth if, qay $\geq$ $p\left(c_{1}\right) b$, or equivalently if

$$
q \geq \theta p\left(c_{1}\right)
$$

In formula (1), where $\theta=b / a y$, which is the ratio of the private benefits that provincial government officials gain from extracted rents (kill growth) to the tax revenue dividends they receive from the central government (foster growth). In other words, the central government's performance-based motivation for provincial government officials (q) must exceed $\theta p\left(c_{1}\right)$. This makes the amount of tax revenue from protecting property rights of businesses that provincial government officials share (qay) exceed that of the private benefits that provincial government officials gain from extracted rents $b p\left(c_{1}\right)$, motivating provincial government officials to protect the property rights of businesses. In this instance, $q$ is relatively larger than $p\left(c_{1}\right)$, indicating that the more that the central government incentives towards economic growth, the tighter that they control provincial level government officials, and therefore the latter has even more motivation and pressure to restrict their behavior.

Next, if the provincial government sequentially decentralizes authority to the prefectural (county) government, investors will have to face the possibility that prefectural (county) officials may violate their rights, so the target of resistance in this case is the prefectural (county) government. In order to simplify our model, we assume that the relationship between the provincial government and the prefectural (county) government replicates that between the central government and the provincial government, where the provincial government has already held a strong position both in rewarding and punishing prefectural officials. The prefectural (county) government shares a taxation quota denoted by $a y$, where $y$ is the whole regional output and dividend ratio $a$ is 
determined absolutely by the provincial government. Under this assumption, the prefectural government chooses growth if:

$$
q \geq \theta p\left(c_{2}\right)
$$

In formula (2), $c_{2}$ represents how much it would cost investors to protect their rights against the prefectural (county) government; we assume $c_{1}>c_{2}, q$ and $p\left(c_{2}\right)$ respectively represent the probability for prefectural (county) officials to remain in their positions if they had protected or violated the rights of private enterprises, and $\theta=b / a y$. Formula (2) implies that only when the degree of performance incentives offered by the provincial government to prefectural (county) officials (denoted by $q$ ) surpass $\theta p\left(c_{2}\right)$ will prefectural (county) officials choose to protect the rights of investors.

In these two sets of formulas, $p\left(c_{1}\right)>p\left(c_{2}\right)$ because $c_{1}>c_{2}$ and $c$ is an incremental function of $p(c){ }^{5}$ With the same value of $q$, the conditions of formula (2) are easier to fulfill. Thus, when comparing this with decentralizing authority to the provincial level, decentralizing to the prefectural level encourages local officials to choose growth, urging them to protect investors' property rights.

\section{Hypothesis}

In order to better discuss how the level of decentralization affects the degree of private property rights protection, two extreme conditions must be excluded.

The first extreme condition is that the central government's performance-based incentives for the local government are ineffective, that is if, $0 \leq q<\theta p\left(c_{2}\right){ }^{6}$ In other words, local officials are more likely to extract rents rather than protect the property rights of investors. At this point, the level of decentralization has no effect on the degree of property rights protection. The other extreme condition appears when the central government has an intense directive for economic growth, as well as tight controls. $\theta p\left(c_{1}\right) \leq q \leq 1,{ }^{7}$ which means that incentives would be enough for local officials to want to choose to foster growth. At this point, the level of decentralization has no effect on the degree of property rights protection. Under either of the extreme conditions, the level of decentralization does not affect the degree of private property rights protection. ${ }^{8}$

In brief, whether the decentralization level affects the degree of property rights protection or not lies in the value of $q$. Only when $q$ lies between the two extreme conditions will the level of decentralization be able to affect the degree of property rights protection for businesses. To do this, the behavior of local officials needs to be restricted. This is dependent on both the incentives and controls of the central government, and the protests and complaints or appeals of investors. This can be shown by $\left(\theta p\left(c_{2}\right), \theta p\left(c_{1}\right)\right)$ which implies that the local government's incentive for growth is neither the highest nor lowest when compared with the extreme conditions. The above discussion can be summarized into the following hypothesis:

Assuming that the central government has a strong ability to supervise and regulate local officials and has a certain policy orientation for economic growth, the local decentralization level has a significant impact on the degree of property rights protection. In particular, the resistance costs for investors are higher when decentralization is only to provincial level, making it difficult for investors to 
influence the behavior of provincial officials through the use of protests and complaints, resulting in a lower degree of property rights protection for private businesses. The resistance costs for investors are lower when decentralization is to the prefectural (county) level, so it is easier for investors to influence the behavior of provincial level officials through protests and complaints, leading to a higher degree of property rights protection for private businesses.

In general, the assumptions for the above hypothesis hold for China. Firstly, the central government has sufficient control over local officials. This means that local officials must respond to the central government's incentive directive. Secondly, the central government's incentive directive for the local government involves multiple targets, with economic growth as one of the most important targets, while other targets such as social stability, social control, environmental protection, production safety, and so on are also of considerable importance. Therefore, we can use the empirical facts of China to evaluate the hypothesis. In the following section, we use the mergers and reorganizations of China's coal industry to compare property rights protection between provinces, and to evaluate our hypothesis.

\section{Mergers and reorganizations of China's coal industry (2008-2013): a comparison of the degree of property rights protection between provinces}

Mergers and reorganizations of the coal industry

Mergers and reorganizations of the coal industry in China was a campaign launched by the State Council, with the objective of increasing coal production, during 20082014. Each province (including autonomous regions and municipalities) carried out decommissioning of obsolete mines, as well as closures and mergers of small coal mines to achieve this. The reason that the State Council initiated the campaign was because, within coal mining, industry concentration was low, technology was outdated, extraction rates were low, it caused serious environmental pollution, there had been countless accidents due to safety issues, and production was unable to meet economic and social needs. ${ }^{9}$

Shanxi Province was first to implement mergers and reorganizations. In September 2008, Shanxi Provincial Government issued a report entitled "Suggestions on how to implement an accelerated process to merge and reorganize coal mine enterprises" (Shanxi Province Issue (2008) No. 23). Subsequently, a series of province-wide implementations of mergers and reorganizations of small coal mines began. In October 2010, based on the experience of Shanxi Province, the State Council General Office submitted "Suggestions on how to implement an accelerated process to merge and reorganise coal mine enterprises" (State Council Issue (2010) No. 46) to the PRC National Development and Reform Commission (NRDC). It required that all coal-producing provinces (including autonomous regions and municipalities) fully implement mergers and reorganizations of small coal mines. It authorized each province to draw up master plans and implementation schedules, suited to their own local circumstances, and then to organize implementation. This meant that the State Council had the administrative authority to implement the mergers and reorganizations allocated to the provincial government. This decentralization allowed provincial governments discretion in developing their own policies and independently implementing such policies. ${ }^{10}$ 


\section{Property rights protection of private coal mines: a comparison of inter-provincial differences}

The campaign involved the closing, merging, and reorganizing of a large number of small coal mines, most of which were privately run, which was probably in direct conflict of interest with the owners of the privately run coal mines. During the mergers and reorganizations, owners of privately run coal mines were concerned about two core issues: (1) Industry access. Compared with state-owned coal mines, owners of private coal mines questioned whether they would have an equal opportunity to become the principal owner of coal mines that were being merged or reorganized, instead of just being passively acquired by state-owned coal mines. (2) Price valuation. Owners were concerned about whether their assets (including their mining rights, which are a type of property right) would receive a fair valuation and whether they would be fairly compensated for their investment if their legitimate coal mine businesses were to be closed, merged, or reorganized according to the campaign agenda. These two concerns will be collectively known as the "degree of property rights protection of privately run coal mines." We employ two methods to assess and compare the differences that emerge between provinces on the degree of property rights protection of privately run coal mines. The first method is to use the results to conduct a comparison of the provinces following mergers and reorganizations, then use the change in the share of outputs of privately run coal mines as a proportion of the total coal output for the whole province so as to assess the overall consequences of the campaign for privately run coal mines, hence property rights protection. The second method is to use policy to conduct a comparison. That is to compare each province's mergers and reorganizations policies, then assess whether privately run coal mines were subject to discrimination based on the policies.

\section{Method 1: assessing the degree of private property rights protection in each province based on the results of the campaign}

Table 1 lists the change before and after the mergers and reorganizations campaign, in each province, of the output share of privately run coal mines as a proportion of the total coal output of that province, between 2008 and 2013. Overall, it shows the effect of the campaign had on privately run coal mines. Except for the four provinces for which no data is available, the rest can be classified into four categories according to the fluctuation rates of their output share after being merged or reorganized. The categories listed in the final column are as follows: provinces whose output share of privately run coal mines had been reduced by $100 \%$; provinces whose output share of privately run coal mines had dropped $10-30 \%$; provinces whose output share of privately run coal mines had dropped between 0 and 10\%; and provinces whose output share of privately run coal mines had not dropped but increased after merger or reorganization. The first category indicates that all privately run coal mines were shut down after the campaign's implementation and includes six provinces-Beijing, Hebei, Shanxi, Hunan, Anhui, and Ningxia. Among these provinces, privately run coal mines were either closed or merged with state-owned mines. The second category consists of only two provinces, Heilongjiang and Liaoning. The third category, which includes a third of the sample, consists of Inner Mongolia, Fujian, Hubei, Yunnan, Chongqing, 
Table 1 Output share of privately run coal mines as a proportion of the province's total coal output before and after the mergers and reorganizations campaign and its fluctuation rate

\begin{tabular}{|c|c|c|c|c|c|c|c|}
\hline & \multicolumn{6}{|c|}{$\begin{array}{l}\text { Output share of privately run coal mines as a proportion of the province's } \\
\text { total coal output (\%) }\end{array}$} & \multirow[t]{2}{*}{$\begin{array}{l}\text { Fluctuation rate } \\
\text { of output share }(\%)\end{array}$} \\
\hline & 2008 & 2009 & 2010 & 2011 & 2012 & 2013 & \\
\hline Beijing & 16.3 & 26.1 & $2.6^{a}$ & 0 & 0 & 0 & -100 \\
\hline Hebei & 3.53 & 2.60 & 1.46 & $1.06^{\mathrm{a}}$ & 0 & 0 & -100 \\
\hline Shanxi & 28.24 & $19.04^{\mathrm{a}}$ & 0 & 0 & 0 & 0 & -100 \\
\hline $\begin{array}{l}\text { Inner } \\
\text { Mongolia }\end{array}$ & 57.08 & 63.50 & 85.25 & $82.52^{\mathrm{a}}$ & 80.47 & - & -5.6 \\
\hline Henan & 34.54 & 27.94 & $0^{a}$ & 0 & 0 & 0 & -100 \\
\hline Heilongjiang & 30.49 & 29.80 & $33.50^{a}$ & 31.10 & 26.66 & 21.0 & -29.5 \\
\hline Jilin & 35.07 & 28.42 & 27.34 & 27.34 & 17.87 & $-^{a}$ & Uncertain \\
\hline Liaoning & 15.74 & 15.00 & 17.50 & 18.69 & $17.01^{a}$ & 16.27 & -12.9 \\
\hline Anhui & 4.51 & 3.50 & 3.30 & 3.60 & $2.47^{a}$ & 0 & -100 \\
\hline Jiangxi & 56.17 & 56.00 & 56.10 & 57.20 & $61.00^{\mathrm{a}}$ & - & Uncertain \\
\hline Fujian & 76.80 & 72.50 & 77.00 & $79.00^{\mathrm{a}}$ & 78.00 & 72.84 & -5.7 \\
\hline Hubei & 82.36 & 85.52 & 88.30 & $89.30^{a}$ & 90.10 & 87.43 & -1.0 \\
\hline Hunan & 81.87 & 91.19 & 90.34 & $91.41^{a}$ & 93.62 & - & +3.5 \\
\hline Sichuan & 77.14 & 76.17 & 76.65 & 74.74 & - & $-{ }^{a}$ & Uncertain \\
\hline Chongqing & 69.45 & 69.20 & 68.50 & 67.30 & $63.05^{\mathrm{a}}$ & 62.86 & -6.9 \\
\hline Guizhou & 75.22 & 74.66 & 75.29 & $76.43^{a}$ & 75.78 & 87.43 & +16.1 \\
\hline Yunnan & 79.06 & 79.80 & 81.60 & $78.55^{\mathrm{a}}$ & 79.37 & - & -2.7 \\
\hline Guangxi & 16.23 & 23.20 & 18.50 & 18.30 & $16.80^{\mathrm{a}}$ & - & Uncertain \\
\hline Shaanxi & 35.13 & 43.35 & 52.06 & $51.74^{\mathrm{a}}$ & 49.05 & 49.04 & -5.8 \\
\hline Gansu & 10.46 & 12.72 & 17.78 & $15.28^{\mathrm{a}}$ & 13.83 & 16.11 & -9.4 \\
\hline Ningxia & 6.93 & 4.26 & $5.22^{\mathrm{a}}$ & 2.90 & 0 & 0 & -100 \\
\hline Xinjiang & 36.80 & 47.26 & $50.74^{\mathrm{a}}$ & 62.65 & 65.41 & - & +38.4 \\
\hline Qinghai & 53.59 & 57.8 & $47.8^{\mathrm{a}}$ & 55.8 & 58 & - & +0.3 \\
\hline
\end{tabular}

Note: (1) "-" indicates missing data; (2) "aа" indicates the starting year of mergers and reorganizations

Source: China Coal Industry Yearbook (National Coal Mine Safety Supervision Bureau, 2008-2013); it excludes Shandong and Jiangsu provinces, as these provinces had almost no privately run coal mines a year before mergers and reorganizations

Shanxi, and Gansu. The last category, which represents provinces that demonstrated an increase, is comprised of Hunan, Guizhou, Xinjiang, and Qinghai.

We believe that the classification of the data above shows significant differences in the degree of property rights protection during the process of mergers and reorganizations. These differences are most clearly demonstrated between the first category and fourth category. In the first category, the campaign led to the shutting down of privately run coal mines, indicating that privately run coal mines received rather poor property rights protection. Firstly, private coal mines in these provinces were not only deprived of industry access, but they had to face either closure or merger with a stateowned coal mine. Secondly, concerning price valuation and compensation, since the owners of privately run coal mines did not have any choice in the matter, they did not receive the same kind of consultation conditions as government or state-owned coal mines did. Hence, it was difficult for them to achieve a fair valuation price or to obtain reasonable compensation. 
In contrast, provinces in the fourth category had a significant increase in output share of privately run coal mines after the campaign was carried out. This indicates that the property rights of privately run coal mines were better protected in these provinces. There are two reasons for this. First, the campaigns in these provinces did not deprive privately run coal mines access to the coal industry but only requested that they expand their production scale and enhance their mining technology. In fact, most of the privately run coal mines that met these basic mining conditions were not merged with state-owned coal mines; instead, they were combined to form joint-stock companies, or through mutual acquisitions, with the aim of meeting the mining conditions that had been set. Second, consider the privately run coal mines being merged or reorganized. Since there were many privately run coal mines in the market that were subject to a merger, there was significantly more choice for these mine owners, especially when negotiating merger conditions or acquisition price. This was because these privately run coal mines that were subjected to mergers were more or less in the same position. The two remaining categories, that is, the second and third, are positioned in between the first and fourth categories. Comparatively speaking, the property rights protection of privately run coal mines in the second category was better than the first; however, it was slightly lower than the third, and it was lower than the fourth.

Method 2: assessing the level of property rights protection of each province's privately run coal mines based on the mergers and reorganizations policies

We focus again on the two core issues (industry access and price valuation) that privately run coal mine owners were concerned about. By working through the main public documents on mergers and reorganizations and complementing the study by looking into mergers and reorganizations plans and the implementation schedule of each province's prefectural government, we have summarized each province's basic policy features for these mergers and acquisitions (refer to Table 2). ${ }^{11}$

According to Table 2, we can further assess if the mergers and reorganization policy in each province was favorable in protecting the property rights of privately run coal mines, as shown in Table 3.

The combination of both methods: comparing the degree of property rights protection for privately run coal mines in all provinces

In comparing Tables 1 and 2, it is easy to see that they are both highly consistent. Following mergers and reorganizations, provinces with a significant decrease in output share from privately run coal mines were precisely those provinces whose policies were not favorable in protecting the property rights of privately run coal mines; whereas the other provinces, whose output share from privately run coal mines that had increased (or slightly decreased), had policies that were favorable (or quite favorable) in protecting property rights of privately run coal mines. The results from Method 1 and Method 2 can be seen in Table 4 . 
Table 2 Basic features of the mergers and reorganizations policy for each province (including autonomous regions and municipalities)

\begin{tabular}{|c|c|c|c|}
\hline \multirow[t]{2}{*}{ Province } & \multicolumn{3}{|c|}{ The basic features of the merger and reorganization policy in each province } \\
\hline & $\begin{array}{l}\text { Who is qualified to merge and } \\
\text { reorganize other coal mines? }\end{array}$ & $\begin{array}{l}\text { What are the positions } \\
\text { of privately run coal mines } \\
\text { in the merger and } \\
\text { reorganization process? }\end{array}$ & $\begin{array}{l}\text { How should the value } \\
\text { of mines merged or } \\
\text { closed be evaluated? }\end{array}$ \\
\hline Beijing & $\begin{array}{l}\text { Only provincial state-owned } \\
\text { enterprises, that is, Beijing Coal } \\
\text { Group, were retained; the rest } \\
\text { of the coal mines were closed }\end{array}$ & Closed & $\begin{array}{l}\text { Compensation standards } \\
\text { laid out by the provincial } \\
\text { government }\end{array}$ \\
\hline Hebei & $\begin{array}{l}\text { The provincial government } \\
\text { assigned two provincial } \\
\text { state-owned coal mine } \\
\text { enterprises_Kailuan Group } \\
\text { and Jizhong Energy Group_as } \\
\text { the main mergers for privately } \\
\text { run coal mines. }\end{array}$ & Merged or closed & $\begin{array}{l}\text { Mining rights are specified } \\
\text { by the provincial government; } \\
\text { valuation is based on the } \\
\text { original price; other assets are } \\
\text { evaluated by the main party } \\
\text { merging and reorganizing }\end{array}$ \\
\hline Shanxi & $\begin{array}{l}\text { The provincial government } \\
\text { assigned eight state-owned } \\
\text { coal mine enterprises as the } \\
\text { main mergers, and designated } \\
\text { merging and reorganizing areas } \\
\text { for each enterprise. }\end{array}$ & $\begin{array}{l}\text { Merged or closed in } \\
\text { principle }\end{array}$ & $\begin{array}{l}\text { Mining rights are regulated by } \\
\text { the provincial government; the } \\
\text { other assets are evaluated by } \\
\text { the main party merging and } \\
\text { reorganizing }\end{array}$ \\
\hline $\begin{array}{l}\text { Inner } \\
\text { Mongolia }\end{array}$ & $\begin{array}{l}\text { Determined by the negotiation } \\
\text { between the prefectural } \\
\text { (county) government and the } \\
\text { coal mine enterprises within } \\
\text { the jurisdiction. }\end{array}$ & $\begin{array}{l}\text { Can apply to be the } \\
\text { main mergers, or join } \\
\text { with other coal mines } \\
\text { to be the mergers. }\end{array}$ & $\begin{array}{l}\text { Evaluated by intermediary } \\
\text { agents, or determined by } \\
\text { the market }\end{array}$ \\
\hline Henan & $\begin{array}{l}\text { The provincial government } \\
\text { assigned five state-owned } \\
\text { enterprises as the main } \\
\text { mergers and designated } \\
\text { merging and reorganizing } \\
\text { areas for each enterprise }\end{array}$ & Merged or closed & $\begin{array}{l}\text { Mining rights are regulated by } \\
\text { the provincial government; the } \\
\text { other assets are evaluated by } \\
\text { the main party merging and } \\
\text { reorganizing }\end{array}$ \\
\hline Heilongjiang & $\begin{array}{l}\text { The provincial government } \\
\text { supported the provincial } \\
\text { enterprise Dragon Coal } \\
\text { Group as the main merger; } \\
\text { the prefectural (county) } \\
\text { government can also } \\
\text { coordinate the list of the } \\
\text { main mergers. }\end{array}$ & $\begin{array}{l}\text { If Dragon Coal Group } \\
\text { and other state-owned } \\
\text { coal mines are not } \\
\text { affected, one can apply } \\
\text { to be the main merger. }\end{array}$ & $\begin{array}{l}\text { Decisions are to be made } \\
\text { through negotiations and } \\
\text { consultations between the } \\
\text { main mergers and reorganizers } \\
\text { and mines being merged or } \\
\text { reorganized }\end{array}$ \\
\hline Jilin & $\begin{array}{l}\text { Enterprises apply on their } \\
\text { own mainly for private } \\
\text { coal enterprises }\end{array}$ & $\begin{array}{l}\text { Can either apply to be the } \\
\text { main mergers, or join with } \\
\text { other coal mines to be the } \\
\text { mergers. }\end{array}$ & $\begin{array}{l}\text { Evaluated by intermediary } \\
\text { agents, or parties involved; } \\
\text { reach an agreement through } \\
\text { voluntary talks }\end{array}$ \\
\hline Liaoning & $\begin{array}{l}\text { The provincial government } \\
\text { supports three provincial } \\
\text { coal mining enterprises as } \\
\text { the main mergers, the rest } \\
\text { are determined by the } \\
\text { prefectural government. }\end{array}$ & $\begin{array}{l}\text { Can join other coal mines } \\
\text { to be the mergers }\end{array}$ & $\begin{array}{l}\text { Coordinated among coal } \\
\text { mine enterprises themselves }\end{array}$ \\
\hline Anhui & $\begin{array}{l}\text { The provincial and municipal } \\
\text { state-owned coal mine } \\
\text { enterprises are the main } \\
\text { mergers }\end{array}$ & Merged or closed & $\begin{array}{l}\text { The provincial government } \\
\text { develops compensation } \\
\text { standards, or may be } \\
\text { evaluated by the main } \\
\text { mergers. }\end{array}$ \\
\hline Jiangxi & $\begin{array}{l}\text { Privately run coal mines can } \\
\text { form to be mergers through } \\
\text { voluntary negotiations }\end{array}$ & $\begin{array}{l}\text { Can either apply to be } \\
\text { the main mergers or join } \\
\text { other coal mines to be } \\
\text { the mergers. }\end{array}$ & $\begin{array}{l}\text { Evaluated by intermediary } \\
\text { agents or parties involved; } \\
\text { reach an agreement through } \\
\text { voluntary talks }\end{array}$ \\
\hline
\end{tabular}


Table 2 Basic features of the mergers and reorganizations policy for each province (including autonomous regions and municipalities) (Continued)

\begin{tabular}{|c|c|}
\hline Fujian & $\begin{array}{l}\text { Determined by negotiation } \\
\text { between the prefectural } \\
\text { (county) government and } \\
\text { the coal mine enterprises, } \\
\text { but priority is given to } \\
\text { state-owned coal mines }\end{array}$ \\
\hline Hubei & $\begin{array}{l}\text { Determined voluntarily (or } \\
\text { jointly) by coal mine } \\
\text { enterprises within the region, } \\
\text { with coordination of the } \\
\text { prefectural (county) } \\
\text { government }\end{array}$ \\
\hline Hunan & $\begin{array}{l}\text { Determined voluntarily (or } \\
\text { jointly) by coal mine } \\
\text { enterprises within the region, } \\
\text { with coordination of the } \\
\text { prefectural (county) } \\
\text { government }\end{array}$ \\
\hline Sichuan & $\begin{array}{l}\text { Determined voluntarily (or } \\
\text { jointly) by coal mine } \\
\text { enterprises within the } \\
\text { region, with coordination } \\
\text { of the prefectural (county) } \\
\text { government }\end{array}$ \\
\hline Chongqing & $\begin{array}{l}\text { Determined voluntarily (or } \\
\text { jointly) by coal mine } \\
\text { enterprises within the region, } \\
\text { with coordination of the } \\
\text { prefectural (county) } \\
\text { government }\end{array}$ \\
\hline Guizhou & $\begin{array}{l}\text { Provincial government } \\
\text { develops qualifications, } \\
\text { coal mine enterprises } \\
\text { apply on their own }\end{array}$ \\
\hline Yunnan & $\begin{array}{l}\text { Determined voluntarily } \\
\text { (or jointly) by coal mine } \\
\text { enterprises within the } \\
\text { region, with coordination } \\
\text { of the prefectural (county) } \\
\text { government }\end{array}$ \\
\hline Guangxi & $\begin{array}{l}\text { Determined voluntarily (or } \\
\text { jointly) by coal mine } \\
\text { enterprises within the } \\
\text { region, with coordination } \\
\text { of the prefectural (county) } \\
\text { government }\end{array}$ \\
\hline Shaanxi & $\begin{array}{l}\text { The provincial state-owned } \\
\text { coal mines are entrusted } \\
\text { with the surrounding small } \\
\text { coal mines, and the } \\
\text { remaining mines are } \\
\text { coordinated by the } \\
\text { prefectural (county) } \\
\text { government }\end{array}$ \\
\hline Gansu & $\begin{array}{l}\text { Determined voluntarily (or } \\
\text { jointly) by coal mine } \\
\text { enterprises within the } \\
\text { region, with coordination } \\
\text { of the prefectural (county) } \\
\text { government }\end{array}$ \\
\hline
\end{tabular}

\author{
Can either apply to be the Evaluated by intermediary \\ main mergers or join other agents or parties involved; \\ coal mines to be the mergers. reach an agreement \\ through voluntary talks
}

Can either apply to be the main mergers or join other coal mines to be the mergers

Evaluated by intermediary agents or coordinated among coal mine enterprises themselves

Can join other coal mines to be the mergers

Evaluated by intermediary agents or parties involved; reach an agreement through voluntary talks

Can either apply to be the main mergers or join other coal mines to be the mergers

Evaluated by intermediary agents or parties involved; reach an agreement through voluntary talks

Can either apply to be the main mergers or join other coal mines to be the mergers

Evaluated by intermediary agents or parties involved; reach an agreement through voluntary talks

Can either apply to be the main mergers or join other coal mines to be the mergers

Evaluated by intermediary agents or parties involved; reach an agreement through voluntary talks

Can either apply to be the main mergers or join other coal mines to be the mergers

Evaluated by intermediary agents or parties involved; reach an agreement through voluntary talks

Can either apply to be the main mergers or join other coal mines to be the mergers

Evaluated by intermediary agents or parties involved; reach an agreement through voluntary talks

Can join with other coal mines to be the mergers in the absence of large state-owned coal mines

Evaluated by intermediary agents or parties involved; reach an agreement through voluntary talks

Can either apply to be the main mergers or join other coal mines to be the mergers
To sell by auction, or parties involved reach an agreement by voluntary talks. 
Table 2 Basic features of the mergers and reorganizations policy for each province (including autonomous regions and municipalities) (Continued)

\begin{tabular}{llll}
\hline Ningxia & $\begin{array}{l}\text { The provincial government } \\
\text { supports state-owned coal } \\
\text { mines as the main mergers } \\
\text { and reorganizers }\end{array}$ & Merged or closed & $\begin{array}{l}\text { Compensation standard } \\
\text { for closed coal mines are } \\
\text { decided by the provincial } \\
\text { and municipal government; } \\
\text { merged coal mines are to } \\
\text { be evaluated by the main } \\
\text { mergers }\end{array}$ \\
Xinjiang & $\begin{array}{l}\text { Determined voluntarily } \\
\text { (or jointly) by coal mine } \\
\text { enterprises within the } \\
\text { region, with coordination } \\
\text { of the prefectural (county) } \\
\text { government }\end{array}$ & $\begin{array}{l}\text { Can either apply to be } \\
\text { the main mergers and } \\
\text { reorganizers or join other } \\
\text { coal mines to be the }\end{array}$ & $\begin{array}{l}\text { Evaluated by intermediary } \\
\text { agents or parties involved; } \\
\text { reach an agreement through } \\
\text { voluntary talks }\end{array}$ \\
& mergers & \\
Qinghai & Continue to operate & \\
reorganizations & if lawful & \\
\hline
\end{tabular}

Source: Relevant documents published by each province, including views, guidance, implementation, and opinions of the merger and reorganization program issued by each provincial government, as well as the implementation plans of the merger and reorganization program issued by some prefectural (county) governments

\section{Level of decentralization and degree of property rights protection: correlation analysis}

Many factors affect the different degree of property rights protection for privately run coal mines between provinces; the most significant of these is the level of decentralization. The "level of decentralization" here refers to the level of local government with administrative authority for mergers and reorganizations. We find a significant correlation between this version of level of decentralization and the degree of property rights protection for privately run coal mines in each province.

\section{Level of decentralization of each province}

The administrative authority that is closely related to mergers and reorganizations, and is a unit according to the administrative area, is the authority to formulate the mergers and reorganizations plan. The main authority for carrying out the campaign was decentralized to local governments on the basis of localized management theory. This included three types of administrative authority: 1 . The authority to determine enterprises qualified to be main merging and reorganizing parties; 2 . The authority to decide the coal mines to be merged (or closed); 3 . The authority to approve limits on merging for main merging enterprises. Three methods were then used to allocate these three types of administrative authority within each province: the first method is that these three types of administrative authority were mainly held by provincial governments, which in principle, were not given to prefectural (county) governments. We define this situation as "decentralization to provincial level". ${ }^{12}$ The second is that the provincial government only identifies the target and the basic principle of the campaign, while the three types of administrative authority are allocated to the prefectural (county) government. In this situation, the prefectural (county) government is responsible for planning the mergers and reorganizations implementation schedule, as well as organizing how to carry it out. This is known as decentralization to prefectural (county) level. The third method lies between the previous two, where a considerable part of administrative authority is allocated to the prefectural (county) government, while the rest 
Table 3 Assessing the degree of property rights protection based on each province's mergers and reorganizations policy

\begin{tabular}{|c|c|c|c|}
\hline Province & $\begin{array}{l}\text { Can privately run coal mines } \\
\text { be main parties in mergers } \\
\text { and or reorganizations either } \\
\text { independently or jointly? }\end{array}$ & $\begin{array}{l}\text { Do coal mines being } \\
\text { merged or reorganized } \\
\text { have equal bargaining } \\
\text { power? }\end{array}$ & $\begin{array}{l}\text { Is the mergers and reorganizations } \\
\text { policy for each province favorable in } \\
\text { protecting property rights of private } \\
\text { coal mine enterprises? }\end{array}$ \\
\hline Beijing & No & No & Very unfavorable \\
\hline Hebei & Not allowed in principle & No & Very unfavorable \\
\hline Shanxi & Not allowed in principle & No & Very unfavorable \\
\hline Inner Mongolia & Yes & More or less equal & Favorable \\
\hline Henan & No & No & Very unfavorable \\
\hline Heilongjiang & Partially allowed & Partially equal & Fairly unfavorable \\
\hline Jilin & Yes & Yes & Favorable \\
\hline Liaoning & Partially allowed & Partially equal & Fairly unfavorable \\
\hline Anhui & No & No & Very unfavorable \\
\hline Jiangxi & Yes & Yes & Favorable \\
\hline Fujian & More or less allowed & More or less equal & Fairly favorable \\
\hline Hubei & Yes & Yes & Favorable \\
\hline Hunan & More or less allowed & Yes & Favorable \\
\hline Sichuan & Yes & Yes & Favorable \\
\hline Chongqing & Yes & Yes & Favorable \\
\hline Guizhou & Yes & Yes & Favorable \\
\hline Yunnan & Yes & Yes & Favorable \\
\hline Guangxi & Yes & Yes & Favorable \\
\hline Shaanxi & Partially allowed & Mostly equal & Fairly favorable \\
\hline Gansu & Yes & Yes & Favorable \\
\hline Ningxia & Not allowed in principle & No & Very unfavorable \\
\hline Xinjiang & Yes & Yes & Favorable \\
\hline Qinghai & & & Fairly favorable \\
\hline
\end{tabular}

Source: Relevant documents issued by each province, including the views, guidance, or implementation of the merger and reorganization program issued by each province, and some by prefectural (county) governments

Table 4 Classification based on the degree of property rights protection in privately run coal mines

\begin{tabular}{|c|c|c|c|}
\hline \multirow{2}{*}{$\begin{array}{l}\text { Degree of property rights } \\
\text { protection of privately run } \\
\text { coal mines }\end{array}$} & \multicolumn{2}{|l|}{ Assessing method } & \multirow[t]{2}{*}{ Province } \\
\hline & Method 1 & Method 2 & \\
\hline High & Increasing $(0-+38.4 \%)$ & \multirow{2}{*}{$\begin{array}{l}\text { Favorable or fairly } \\
\text { favorable }\end{array}$} & Hunan, Guizhou, Xinjiang, Qinghai \\
\hline Fairly high & $\begin{array}{l}\text { Decreasing slightly } \\
(0 \text { to }-10 \%)\end{array}$ & & $\begin{array}{l}\text { Fujian, Hubei, inner Mongolia, } \\
\text { Yunnan, Chongqing, Shaanxi, Gansu }\end{array}$ \\
\hline Fairly low & $\begin{array}{l}\text { Decreasing significantly } \\
(-10 \text { to-30\%) }\end{array}$ & Fairly unfavorable & Heilongjiang, Liaoning \\
\hline Low & $-100 \%$ & Very unfavorable & $\begin{array}{l}\text { Beijing, Hebei, Shanxi, Henan, Anhui, } \\
\text { Ningxia }\end{array}$ \\
\hline
\end{tabular}


remains in the hands of the provincial government. This situation is referred to as "partial decentralization to prefectural (county) level."

In accordance with the definition above, we have measured the decentralization level of each province by analyzing their main formal documents for mergers and reorganizations and using the implementation schedules formulated by a number of prefectural (county) governments as reference (see Table 5).

\section{Correlation between the level of decentralization and the degree of property rights protection}

Comparing Table 4 with Table 5, there exists a clear correlation between the level of decentralization and the degree of property rights protection in each province. This allows us to infer that when the level of decentralization is lower, that is, closer to the prefectural (county) level, the degree of property rights protection for privately run coal mines is higher (see Table 6).

\section{Hypothesis test}

As shown, empirical study of the campaign implementation in each province has revealed a significant correlation between the level of decentralization and the degree of private property rights protection, but whether the assumption and mechanism of the hypothesis is significant needs further testing.

In order to further explain this type of relationship, we can conduct an empirical study to test the hypothesis. We need to develop our discussion in two respects. First, we illustrate that the mergers and reorganizations implemented by the coal industry in each province were in keeping with the assumptions of the hypothesis, and therefore inferences can be drawn based on the hypothesis. Second, we show that the inference from the hypothesis is true, namely that the reason why the level of decentralization affects the degree of property rights is because it can influence investors' resistance costs, thereby affecting the levels of restriction experienced by local officials.

\section{Assumption test: central government's tight control over local officials and incentive directive}

One of the hypothesis assumptions, that the central government maintains tight control over the local officials, clearly holds in the coal mine industry. There is no need to elaborate on this point. Our discussion focuses instead on another assumption of the hypothesis, that the central government directs a certain policy orientation for economic growth, and at the same time, this type of growth directive does not have enough power to prevail over other targets. In the regulation of China's coal mine industry, the central government not only emphasizes the importance of economic growth, but also emphasizes other targets, such as production safety, environmental protection, and the efficiency of mining natural resources. During the mergers and reorganizations of the coal industry, the incentive directive of the central government for the provincial level governments was multi-dimensional: Not only did the central government stress economic development, requiring each province to achieve sustainable development of its coal industry through mergers and reorganizations, it also stressed production safety and the protection of resources and the local environment, requiring 
Table 5 Level of decentralization in each province

\begin{tabular}{|c|c|c|c|c|}
\hline \multirow[t]{2}{*}{ Province } & \multicolumn{3}{|c|}{$\begin{array}{l}\text { The level of government that mainly holds administrative authority during } \\
\text { mergers and reorganizations }\end{array}$} & \multirow[t]{2}{*}{$\begin{array}{l}\text { Level of } \\
\text { decentralization }\end{array}$} \\
\hline & $\begin{array}{l}\text { The authority to determine } \\
\text { qualified enterprises to be } \\
\text { the primary merging and } \\
\text { reorganizing parties }\end{array}$ & $\begin{array}{l}\text { The authority to } \\
\text { decide the coal } \\
\text { mines that are to be } \\
\text { merged (or closed) }\end{array}$ & $\begin{array}{l}\text { The authority to approve } \\
\text { merging and reorganizing } \\
\text { limits of the primary } \\
\text { merging enterprises }\end{array}$ & \\
\hline Beijing & Provincial government & $\begin{array}{l}\text { Provincial } \\
\text { government }\end{array}$ & - & Provincial level \\
\hline Hebei & Provincial government & $\begin{array}{l}\text { Provincial } \\
\text { government }\end{array}$ & Provincial government & Provincial level \\
\hline Shanxi & Provincial government & $\begin{array}{l}\text { Provincial } \\
\text { government }\end{array}$ & Provincial government & Provincial level \\
\hline $\begin{array}{l}\text { Inner } \\
\text { Mongolia }\end{array}$ & $\begin{array}{l}\text { Prefectural (county) } \\
\text { government }\end{array}$ & $\begin{array}{l}\text { Prefectural (county) } \\
\text { government }\end{array}$ & $\begin{array}{l}\text { Prefectural (county) } \\
\text { government }\end{array}$ & $\begin{array}{l}\text { Prefectural } \\
\text { (county) level }\end{array}$ \\
\hline Hunan & Provincial government & $\begin{array}{l}\text { Provincial } \\
\text { government }\end{array}$ & Provincial government & Provincial level \\
\hline Heilongjiang & $\begin{array}{l}\text { Partial prefectural } \\
\text { (county) government }\end{array}$ & $\begin{array}{l}\text { Prefectural (county) } \\
\text { government }\end{array}$ & $\begin{array}{l}\text { Partial prefectural } \\
\text { (county) government }\end{array}$ & $\begin{array}{l}\text { Partial prefectural } \\
\text { (county) level }\end{array}$ \\
\hline Jilin & $\begin{array}{l}\text { Prefectural (county) } \\
\text { government }\end{array}$ & $\begin{array}{l}\text { Prefectural (county) } \\
\text { government }\end{array}$ & $\begin{array}{l}\text { Prefectural (county) } \\
\text { government }\end{array}$ & $\begin{array}{l}\text { Prefectural } \\
\text { (county) level }\end{array}$ \\
\hline Liaoning & $\begin{array}{l}\text { Partial prefectural } \\
\text { (county) government }\end{array}$ & $\begin{array}{l}\text { Prefectural (county) } \\
\text { government }\end{array}$ & $\begin{array}{l}\text { Partial prefectural } \\
\text { (county) government }\end{array}$ & $\begin{array}{l}\text { Partial prefectural } \\
\text { (county) level }\end{array}$ \\
\hline Anhui & Provincial government & $\begin{array}{l}\text { Provincial } \\
\text { government }\end{array}$ & $\begin{array}{l}\text { Partial prefectural } \\
\text { (county) government }\end{array}$ & Provincial level \\
\hline Jiangxi & $\begin{array}{l}\text { Prefectural (county) } \\
\text { government }\end{array}$ & $\begin{array}{l}\text { Prefectural (county) } \\
\text { government }\end{array}$ & $\begin{array}{l}\text { Prefectural (county) } \\
\text { government }\end{array}$ & $\begin{array}{l}\text { Prefectural } \\
\text { (county) level }\end{array}$ \\
\hline Fujian & $\begin{array}{l}\text { Prefectural (county) } \\
\text { government }\end{array}$ & $\begin{array}{l}\text { Prefectural (county) } \\
\text { government }\end{array}$ & $\begin{array}{l}\text { Prefectural (county) } \\
\text { government }\end{array}$ & $\begin{array}{l}\text { Prefectural } \\
\text { (county) level }\end{array}$ \\
\hline Hubei & $\begin{array}{l}\text { Prefectural (county) } \\
\text { government }\end{array}$ & $\begin{array}{l}\text { Prefectural (county) } \\
\text { government }\end{array}$ & $\begin{array}{l}\text { Prefectural (county) } \\
\text { government }\end{array}$ & $\begin{array}{l}\text { Prefectural } \\
\text { (county) level }\end{array}$ \\
\hline Hunan & $\begin{array}{l}\text { Prefectural (county) } \\
\text { government }\end{array}$ & $\begin{array}{l}\text { Prefectural (county) } \\
\text { government }\end{array}$ & $\begin{array}{l}\text { Prefectural (county) } \\
\text { government }\end{array}$ & $\begin{array}{l}\text { Prefectural } \\
\text { (county) level }\end{array}$ \\
\hline Sichuan & $\begin{array}{l}\text { Prefectural (county) } \\
\text { government }\end{array}$ & $\begin{array}{l}\text { Prefectural (county) } \\
\text { government }\end{array}$ & $\begin{array}{l}\text { Prefectural (county) } \\
\text { government }\end{array}$ & $\begin{array}{l}\text { Prefectural } \\
\text { (county) level }\end{array}$ \\
\hline Chongqing & $\begin{array}{l}\text { Prefectural (county) } \\
\text { government }\end{array}$ & $\begin{array}{l}\text { Prefectural (county) } \\
\text { government }\end{array}$ & $\begin{array}{l}\text { Prefectural (county) } \\
\text { government }\end{array}$ & $\begin{array}{l}\text { Prefectural } \\
\text { (county) level }\end{array}$ \\
\hline Guizhou & $\begin{array}{l}\text { Prefectural (county) } \\
\text { government }\end{array}$ & $\begin{array}{l}\text { Prefectural (county) } \\
\text { government }\end{array}$ & $\begin{array}{l}\text { Prefectural (county) } \\
\text { government }\end{array}$ & $\begin{array}{l}\text { Prefectural } \\
\text { (county) level }\end{array}$ \\
\hline Yunnan & $\begin{array}{l}\text { Prefectural (county) } \\
\text { government }\end{array}$ & $\begin{array}{l}\text { Prefectural (county) } \\
\text { government }\end{array}$ & $\begin{array}{l}\text { Prefectural (county) } \\
\text { government }\end{array}$ & $\begin{array}{l}\text { Prefectural } \\
\text { (county) level }\end{array}$ \\
\hline Guangxi & $\begin{array}{l}\text { Prefectural (county) } \\
\text { government }\end{array}$ & $\begin{array}{l}\text { Prefectural (county) } \\
\text { government }\end{array}$ & $\begin{array}{l}\text { Prefectural (county) } \\
\text { government }\end{array}$ & $\begin{array}{l}\text { Prefectural } \\
\text { (county) level }\end{array}$ \\
\hline Shaanxi & $\begin{array}{l}\text { Prefectural (county) } \\
\text { government }\end{array}$ & $\begin{array}{l}\text { Partial prefectural } \\
\text { (county) government }\end{array}$ & $\begin{array}{l}\text { Prefectural (county) } \\
\text { government }\end{array}$ & $\begin{array}{l}\text { Prefectural } \\
\text { (county) level }\end{array}$ \\
\hline Gansu & $\begin{array}{l}\text { Prefectural (county) } \\
\text { government }\end{array}$ & $\begin{array}{l}\text { Prefectural (county) } \\
\text { government }\end{array}$ & $\begin{array}{l}\text { Prefectural (county) } \\
\text { government }\end{array}$ & $\begin{array}{l}\text { Prefectural } \\
\text { (county) level }\end{array}$ \\
\hline Ningxia & Provincial government & $\begin{array}{l}\text { Provincial } \\
\text { government }\end{array}$ & Provincial government & Provincial level \\
\hline Xinjiang & $\begin{array}{l}\text { Prefectural (county) } \\
\text { government }\end{array}$ & $\begin{array}{l}\text { Prefectural (county) } \\
\text { government }\end{array}$ & $\begin{array}{l}\text { Prefectural (county) } \\
\text { government }\end{array}$ & $\begin{array}{l}\text { Prefectural } \\
\text { (county) level }\end{array}$ \\
\hline Qinghai & Without merger & $\begin{array}{l}\text { Prefectural (county) } \\
\text { government }\end{array}$ & $\begin{array}{l}\text { Prefectural (county) } \\
\text { government }\end{array}$ & $\begin{array}{l}\text { Prefectural } \\
\text { (county) level }\end{array}$ \\
\hline
\end{tabular}

Source: Documents of mergers and reorganizations issued by each province and some prefectures (counties) 
Table 6 Correlation between the level of decentralization and the degree of property rights protection

\begin{tabular}{lll}
\hline Level of decentralization & Province & $\begin{array}{l}\text { Degree of protection of property } \\
\text { rights in private coal mines }\end{array}$ \\
\hline Provincial level & $\begin{array}{l}\text { Beijing, Hebei, Shanxi, Hunan, Anhui, } \\
\text { Ningxia }\end{array}$ & Low \\
Partial prefectural (county) level & $\begin{array}{l}\text { Heilongjiang, Liaoning } \\
\text { Prefectural (county) level }\end{array}$ & $\begin{array}{l}\text { Fujian, Hubei, Inner Mongolia, Yunnan, } \\
\text { Chongqing, Shaanxi, Gansu }\end{array}$ \\
& Hunan, Guizhou, Xinjiang, Qinghai & Fairly high \\
& & High \\
\hline
\end{tabular}

provinces to improve production safety conditions, increase the recovery rate of coal resources, and strengthen the degree of environmental protection. ${ }^{13}$ This type of multitargeting in incentive directives is consistent with the assumptions of the hypothesis. Meanwhile, under the control of the central government, such multi-targeting is also practiced within the provincial government's policy directive for the prefectural (county) government, which is consistent with the incentives directive of the central government.

Mechanism test: reasons that the level of decentralization affects the degree of property rights protection

In this section, we will test the vertical constraints mechanism. As the hypothesis inferred, the resistance cost can be changed according to decentralization level, thereby affecting property rights protection.

During mergers and reorganizations, the owner of the privately run coal mine had three sets of resistance costs: (1) the organization costs of collective resistance. This was how much it would cost private coal investors to organize protests and complaints against local governments; (2) the extra cost exerted by the government's repression behaviors. This was investors' loss caused by the government's suppressive measures, which may directly cause them to withdraw from resistance; (3) the cost of mobilizing higher authorities to intervene. This was the cost required for private coal investors to petition, write open letters, seek media help so as to gain attention from the central government (or provincial government) and subsequently mobilize them to intervene. By comparing the variation in the three sets of resistance costs, based on different levels of decentralization, we can compare how the level of decentralization affects resistance costs of owners of privately run coal mines.

\section{A comparison of organizational costs}

Owners of privately run coal mines intending to put pressure on local governments must organize collective resistance, such as collective protests and group complaints, the cost of which lies in the number of resistant owners, their geographical location, the degree of organization and other factors. The higher the number of owners of privately run coal mines, the more scattered the geographical location, the higher the cost of organizing collective resistance. Obviously, the level of decentralization affects these factors, which in turn affects organizational costs.

At the provincial level of decentralization, initiating collective resistance against provincial officials requires all the owners to be involved, since owners of privately run coal 
mines within the entire province must be organized and mobilized. However, in every province, individual owners have a relaxed attitude, no province-level industry organization has been established, and these factors make organization very difficult and very costly. By contrast, if decentralization has happened at the prefectural (county) level, prefectural (county) officials have to deal with owners' resistance instead, which makes organizational costs of resistance relatively lower. Within a prefectural (county) region, owners of privately run coal mines usually have a close network of interpersonal relationships; in addition, there are usually many private mining industry organizations in most prefectures (counties), normally known as the County Coal Industry Association. Under such circumstances, it is much easier to coordinate the actions of owners of privately run coal mines. Thus, when compared to decentralizing to the provincial level, the organizational costs of collective resistance are greatly reduced when decentralizing to the prefectural (county) level.

\section{Comparison of the costs exerted by local governments}

The costs exerted by local governments are proportional to the ability of local governments to suppress investors and inversely proportional to the extent of favorable relations that they have with owners. Compared with the prefectural (county) government, the provincial government is more powerful when it comes to suppressing resistance. Besides this, it has a larger police force, more judicial power, more control of political and economic resources, and it can order the prefectural (county) government to take suppressive actions. Therefore, owners of privately run coal mines resisting against the provincial government means they will face more consequences than if they had resist against the prefectural (county) government. Moreover, the provincial government generally will not establish any direct relations with owners of privately run coal mines and so provincial officials are less affected when handling their resistance. In contrast, not only does the prefectural (county) government have less power to suppress any resistance, the prefectural (county) officials often have a variety of connections with the owners of privately run coal mines. Usually unless there is strong political pressure, prefectural (county) governments are generally reluctant to use any force to suppress. Therefore, compared with the provincial level of decentralization, the resistance cost exerted by local governments is greatly reduced by decentralizing to the prefectural (county) level.

\section{Comparison of the Costs of Mobilizing Higher Levels of Governments to Intervene}

In general, the cost of mobilizing the higher governments is proportional to the level of authority. The higher the authority level, the greater the difficulty of mobilizing, and the higher the resistance cost of mobilizing. At the provincial level of decentralization, it is difficult for owners of privately run coal mines to resist the provincial government, due to the fact that they would need to mobilize the central government to intervene; whereas at the prefectural (county) level, resisting them is lessened as owners of privately run coal mines need only to mobilize either the central government or the provincial government to intervene, and thus owners have more options. Therefore, compared with the provincial level of decentralization, the prefectural (county) level of decentralization can reduce the costs of mobilizing higher authority levels. 
To sum up the three sets of costs above, we can draw the following conclusion: the resistance costs for owners of privately run coal mines can be fairly high when authority has only been decentralized to the level of the provincial government. In contrast, decentralizing to prefectural (county) level can effectively reduce resistance costs. This would then suggest that it is possible to test the mechanism of the hypothesis by analyzing the relationships between resistance costs and level of decentralization. That is, compared with decentralizing to the provincial level, decentralizing to the prefectural (county) level means investors are more likely to be able to constrain the prefectural government due to their lowered resistance costs, thereby making it more favorable for their property rights to be protected. The theoretical analysis above supports the hypothesis.

Two representative case studies: a comparison of resistance costs of coal mine owners in Shanxi and Guizhou

In order to further test the hypothesis and its mechanism, we examine the specific evidence of two representative provinces, indicating how the level of decentralization affects the resistance costs of privately run coal mine owners, thereby its effect on the degree of property rights protection of privately run coal mines.

Both Shanxi and Guizhou are provinces with enormous coal production, but their privately run coal mines experienced very different soutcome after the merger and reorganization campaign. In Shanxi Province, private coal mines basically disappeared after the campaign's implementation. Not only did owners of the privately run coal mines fail to effectively resist the government's infringement on their rights but also they were forced to accept the adverse consequences of the campaign. The owners of the privately run coal mines in Guizhou Province also faced the arbitrary local policy, but they were able to defend their rights through collective resistance. After mergers and reorganizations, their output share did not drop, but actually increased. In both of these provinces, the owners of the privately run coal mines all had to face the possibility of infringement from local officials, and they all had strong incentives to protect their rights through resistance, so why did the owners react so differently to the violation of their rights? We will argue that this difference arises from the fact that the campaign was implemented through different levels of decentralization in the two provinces.

\section{Resistance dilemmas of the owners of the privately run coal mines in Shanxi}

In Shanxi, implementing the merger and reorganization campaign of the coal mine industry was directly organized by the provincial government; at the same time, the prefectural government was utilized to control the owners of the privately run coal mines. This particular working relationship forced the owners of the privately run coal mines into difficult dilemmas concerning resistance.

More importantly, the merger and reorganization policy in Shanxi had two major distinguishing features. First, the provincial government designated eight state-owned coal mine enterprises as the province's main merging and reorganizing parties for implementation of the campaign, and designated their respective regions of merging and reorganizing so as to avoid competition. ${ }^{14}$ In order to encourage the prefectural government to implement these policies, the provincial government also allowed the 
prefectural government to propose local state-owned coal enterprises from their own prefecture as a main party merger and reorganizer; once their proposals were submitted to the provincial government and then checked and approved, the local state-owned coal enterprises of the prefectural government were allowed to be mergers and reorganizers and participate in the campaign within their prefectural region. The campaign implementation of the coal industry in Shanxi province is under the leadership of the provincial government, which allowed the provincial and prefectural (county) governments to re-allocate the mining rights of the coal resources. Second, as for the mines being merged and reorganized, their price valuation and compensation principles were also developed by the provincial government.

Obviously, these policies were very unfavorable to privately run coal mines. In order to carry out the campaign, the provincial government assumed a vetoing system: the prefectural officials who did not complete tasks that the provincial government assigned on time would automatically fail their annual assessment. The prefectural government adopted the same one-vote veto approach to their subordinates who were responsible for completing campaign work. This can be seen by the information issued by the prefectural government of Jincheng on April 29, 2009.

Each county government is completely responsible for the merger and reorganization tasks of that administrative area. The prefectural government will assess and report the quarterly progress of the merger and reorganization program carried out by each county (city, district) government. The leaders of any county (city, district) government failing to have merged or closed down privately run coal mines on time will fail their annual assessment by the onevote veto policy. ${ }^{15}$

Under high pressure from the provincial and prefectural governments, county (city and district) governments in Shanxi Province went all out to compel owners of privately run coal mines to accept the government's price valuations and compensation standard, and to sign agreements with the state-owned enterprises that the provincial government had designated (Cao and Li 2009). Owners who refused to give in, or might have caused trouble, to the county (city, district) governments were also dealt with, including cutting off their power and water supply, and stopping their production, as well as investigating whether or not they had had any history of tax evasion. This illustrates the huge conflicts of interest between the owners of the privately run coal mines being merged through the mergers and reorganizations that the local government designated and the main merging and organizing parties. In most cases, the local government acknowledged that owners found it impossible to accept the evaluated prices and compensation. ${ }^{16}$

However, during the mergers and reorganizations program, owners of privately run coal mines did not initiate collective resistance in Shanxi. The reason was that they had fallen into the traps that had been arranged by the local governments: In the event that owners attempted to resist the county government's efforts to force them to sign unfair agreements, the county government would argue that they were only carrying out the orders of the prefectural or provincial government; if owners of privately run coal mines resisted the provincial government, they might have faced extremely high 
resistance costs exerted by the prefectural (county) government. They were not allowed to resist within Shanxi's provincial region because the provincial government not only had violence as an advantage, but it could also utilize the prefectural and county governments to control the owners of privately run coal mines. ${ }^{17}$ Therefore, for the owners of privately run coal mines, the cost of protecting their property rights was very high in Shanxi, and it is difficult for the vertical constraints mechanism to be effective in constraining the local government.

It is noteworthy that owners from Zhejiang Province, who were unable to resist in Shanxi, had to return to Zhejiang to appeal. Through the media and lawyers, the Zhejiang mine owners initiated a series of resistance actions against the Shanxi provincial government for violating their rights. ${ }^{18}$ They filed complaints to the Standing Committee of the National People's Congress through the Zhejiang Provincial Investment Promotion Association, questioning the policy legitimacy of Shanxi's coal mine merger and reorganization campaign, as well as appealing to the central government to protect the legal rights and interests of private businesses in Shanxi. ${ }^{19}$ However, the resistance that occurred in Zhejiang did not have any substantial impact on the Shanxi provincial government. In the end, such resistance neither drove the Shanxi government to change its policy, nor did it cause the central government to intervene.

Even though the owners of the privately run coal mines initiated resistance in Zhejiang Province, none of them made an appearance before the media, fearing the punishment that the local Shanxi government might cause them to endure. ${ }^{20}$ Ultimately, these businessmen from Zhejiang suffered huge losses, and the majority of them sadly left Shanxi.

\section{Resistance action taken by owners of privately run coal mines in Guizhou Province}

By contrast, Guizhou Province launched its mergers and reorganizations of coal mines in April 2011, by selecting to decentralize the power of decision-making to the prefectural (county) level, thus empowering the prefecture and its subordinates with authority to carry out the campaign. The provincial government broke down the main tasks of the campaign, such as the number of coal mine enterprises and mines being retained after the mergers and reorganizations, to each prefectural government. ${ }^{21}$ Each prefectural government further had the mergers and reorganizations targets split within subordinate governments (county and district), and the relevant administrative authority was granted to them. Thus, relevant powers for the campaign were largely decentralized to the county level. ${ }^{22}$

However, since county level governments had the authority to determine qualified enterprises to be main merging and reorganizing parties as well as the authority to decide the coal mines to be merged (or closed), county governments also had the potential to violate property rights. For example, before the campaign was carried out, there were 117 coal mines in Jinsha County, a county of Bijie prefecture, all of which belonged to more than 50 coal mine enterprises, and the vast majority of which were private. ${ }^{23}$ Bijie prefectural government assigned the main tasks to Jinsha county government, who requested that the number of coal mines be cut through "mergers and reorganizations" to around 10 mines. In early May 2011, Jinsha County government developed a list of enterprises that were going to be the main merging and reorganizing parties, stipulating that coal mines with an annual output of 90,000 tons or less were to 
be closed, while the rest must be merged or reorganized to one of the main merging and reorganizing enterprises on the list. Soon afterwards, the county government convened a meeting of coal mine investors within the region, announcing a detailed plan for the campaign and gave coal mine enterprises on the list a month to finish negotiating and to reach agreements with other mines. Many coal mine owners had questioned county government leaders at the meeting, asking How did the list of main merging and reorganizing parties emerge? Why did some enterprises qualify to be a main merging and reorganizing party, while others with a similar production capacity must face merging? Who should bear the investment loss if the government wants to close our mines? The leader of the county government was unable to answer these questions satisfactorily.

After this meeting, some owners of privately run coal mines within Jinsha County started to plan resistance actions, through contacts in the County Coal Industry Association (a semi-official organization in the county) in order to protect their property rights. On the morning of May 26, 2011, more than 50 coal mine owners, along with some mine workers, gathered on the square in front of the Jinsha County government building, with resistannce slogans such as "Private coal to survive," "Not made to merge, but made to purge," for the protest against the county government. That afternoon, the county government immediately called on the representatives of the mine owners to carry out negotiations, promising that the demands of the mine owners would be submitted to the provincial government as soon as possible, and acquiesced to the request that privately run coal mines be allowed to form joint-stock enterprises so that one of the tasks of the campaign (to reduce the number of coal mine enterprises) could be achieved. Since then, most of the privately run coal mines in Jinsha County have been spontaneously forming as joint-stock enterprises, so as to meet the provincial government's requirements for the campaign. As for the coal mines that had to be closed, coal mine owners found an alternative method by selling them to enterprise owners who wished to be main merging or reorganizing parties. In this way, buyers closed the purchased mines, and then declared it to the government. Adding the existing reserves of the mine and its production capacity to the buyer's total existing reserves and their total production capacity helped buyers increase production capacity to the provincial government requirement of 200 million tons per year. ${ }^{24}$

In the second half of 2012, some owners of privately run coal mines in Jinsha County presented a petition to Guizhou Provincial government, reporting the problems during the process of campaign implementation and made requests. The Vice Governor in charge of industries in Guizhou Province made a special trip to the city of Bijie, inspecting the work of the mergers and reorganizations, and gathered coal mine investors within the city of Bijie into a forum to listen to their views and their demands. ${ }^{25}$

In December 2012, a newly revised document was issued by the Guizhou provincial government, entitled "The work programme of coal mine mergers and reorganizations in Guizhou" (Guizhou sheng meikuang qiye jianbing chongzu gongzuo fangan), in which significant adjustment was made to the mergers and reorganizations policy to be more favorable in protecting privately run coal mines. The new "program" specified that the coal enterprise can freely apply to be a main merging or reorganizing party, and it was no longer designated by the prefectural (county) government. Instead, prefectural (county) governments now only take responsibility for examining the credentials of the 
applicant and then submit it along to the provincial government for confirmation. In addition, the qualification for being a main merging or reorganizing party was also released to the public. The main condition was that the enterprise's yearly production capacity could not be lower than 1.5 million tons (the cities of Liupanshui and Bijie in Guizhou had limits of 2 million tons per year). The revised policies indicated that the provincial government had publicly acknowledged the legitimacy of Jinsha's practice, where private coal mine enterprises can meet the qualification by forming joint-stock enterprises.

\section{Conclusion and discussion}

The social perspective of property rights is the process by which property rights and their results are defined from a public or societal viewpoint; however, this perspective does not exclude the influence of government.

On the contrary, this perspective helps analyze how decentralization affects peoples' capability to resist (or ability to protest) and their resistance costs, and how this further influences the social construction outcome of property rights. Our findings show that within the decentralized governance structure, apart from being able to use the mechanism of interjurisdictional constraints, investors can also make use of the vertical constraints mechanism to protect their property rights. The effectiveness of the vertical constraints mechanism however, relies on the resistance costs of investors. Compared with decentralizing to the provincial level, decentralizing to the prefectural level not only reduces resistance costs, but it also strengthens the vertical constraints mechanism and therefore heightens the degree of property rights protection for private businesses.

The analysis in this article shows that the social perspective of property rights has the potential to be further developed. Introducing the decentralized governance structure into the analysis framework results in a stronger argument. Moreover, an additional conclusion drawn from this article suggests that another inference can be made, which is that the "widely accepted principle of fairness" is insufficient. Sociologists brought it to light in research on defining property rights, which was based on the reform of township and village enterprises, and collective landownership in villages (Zhang 2003, 2005; Zhe and Chen 2004, 2005; Shen and Wang 2005; Liu 2003a, 2003b; Institute of Sociology, 2006). The process, in which these types of property rights are defined, happens when there has been decentralization to prefectural (county) level or lower. This study shows that such an argument is significant only if the main administrative authority is decentralized to the prefectural (county) level. Only when the prerequisite conditions are met, the principle of fairness and the voice of people may significantly affect the social construction outcome of property rights.

\section{Endnotes}

1"The social perspective of ownership" originated in the 5th volume of "Chinese Sociology" (2006), edited and published by the Institute of Sociology at the Chinese Academy of Social Sciences. This volume included five articles based on Chinese sociologists' studies on the issue of ownership.

${ }^{2}$ For investors, there are some key production factors, e.g., land, mineral resources, buildings, infrastructure, etc., that are immoveable. In which case, with regard to interjurisdictional competition theory, for those enterprises whose key factors can flow 
freely among regions, the answer for the above question is positive; but if it is difficult for such key factors to flow freely among regions, the answer is negative.

${ }^{3}$ In this article, we ignore township government, because the township area is small and the government's function is not complete. At the same time, we include the municipal government and county-level government, referring to them collectively as the city (county) government. The reason for this simplification is that the county government, although under the jurisdiction of the municipal government, in terms of the administration, basically has the same administrative authority as the municipal government.

${ }^{4}$ The cost of rights protection includes three parts: first is the cost of the protest initiated by the investor against the local government; second is that the local government may take action to suppress investors such that investors involved in the protest would experience loss of interests; last is that the cost of investors filing complaints to the central government, mobilizing it to pay attention and interfere. See the "Hypothesis test" section of this article for details.

${ }^{5}$ The reasoning is as follows: First, $c_{1}>c_{2}$, the reason is, relative to protesting against the prefectural (county) government, if investors target the provincial government to protest and complain, not only do they have to be organized in a wider range as they face suppression from more powerful governments, they also need to mobilize the central government for attention and intervention, in which case, the cost of rights protection tends to be high (see the "Hypothesis test" section of this article). Secondly, $p(c)$ is the increasing function of c, that is, $p(c)>0$. The reason is that when investors' rights costs fall, they are more likely to protest and complain, and are more likely to attract the attention and involvement of the central government (or provincial government) in the face of local officials' infringement of corporate property rights. The probability that local officials will continue to serve; therefore, $p\left(c_{1}\right)>p\left(c_{2}\right)$.

${ }^{6}$ This condition means $0 \leq q<\theta p\left(c_{2}\right)$. In this case, we also obtain $q<\theta p\left(c_{1}\right)$ because of $p\left(c_{1}\right)>p\left(c_{2}\right)$, that is, condition (1) and condition (2) are not established.

${ }^{7}$ This condition means that $\theta p\left(c_{1}\right) \leq \mathrm{q} \leq 1$. In this interval, the performance incentive intensity $(q)$ is large enough, both greater than $\theta p\left(c_{1}\right)$ and greater than $\theta p\left(c_{2}\right)$, so the condition (1) and condition (2) are tenable.

${ }^{8}$ There are two reasons for this result. One reason is that the central government's incentive for provincial governments to perform, or the provincial governments' incentive for prefectural (county) governments to perform, has seriously deviated from targets of economic growth, resulting in local officials lacking the incentive to promote economic growth. Another reason is that the central government's ability to supervise provincial governments, or the provincial governments' ability to supervise prefectural (county) governments, is severely inadequate, resulting in the central government (and provincial government) being difficult to reward and punish local officials, while local officials do not have to pay attention to economic performance either.

${ }^{9}$ The State Council Office issued "A number of opinions on speeding up the merger and reorganization of coal mining enterprises," (2010) No. 46, October 16, 2010.

${ }^{10}$ Before the mergers and reorganizations in the provinces, on October 7, 2008, the National Development and Reform Commission joined the National Energy Bureau, the State Administration of Work Safety, and the State Coal Mine Safety Supervision Bureau to issue "Notice on the Closure of Small Coal Mines three years after the 
'Eleventh Five-Year' Plan" to all provinces. This notice showed that in 2008, the country had 14,069 small mines with a total annual output under 300,000 tons, of which 2501 would be closed within 3 years and another 1616 would undergo technological transformation or be supervised by state-owned coal mine enterprises. By the end of 2010, the total number of small coal mines was reduced to 9952. This plan later became the main basis by which provinces determined the objectives of mine mergers and reorganizations.

${ }^{11}$ As for detailed documents on the merger and reorganization of each province, due to the limited length of this article, they cannot be listed one by one; those interested in these documents can request them from the authors.

${ }^{12}$ Of course, the provincial government has the authority to develop a merger and reorganization policy, but it must be implemented by the prefectural (county) government. The prefectural (county) government only has the responsibility for implementation; it does not have policy making powers.

${ }^{13}$ See "A number of opinions on accelerating the merger and reorganization of coal mines" by the State Council General Office of the Development and Reform Commission, (2010) 46, October 16, 2010.

${ }^{14}$ The eight state-owned coal mining enterprises are: Datong Coal Mine Group, Shanxi Coking Coal Group, Yangquan Coal Group, Lu'an Mining Group, Jincheng Anthracite Group, Shanxi Coal Transportation and Marketing Group Corporation, Shanxi Coal Import and Export Corporation, and China Coal Energy Pingshuo Company. Among them, China Coal Energy Pingshuo Company is a central government-owned enterprise; the rest are Shanxi provincial government-owned enterprises. Shanxi Provincial People's Government: "On the Accelerated Implementation of the Merger and Reorganization of Coal Mining Enterprises" (Jin ZhengFa (2008) 23), and the Shanxi Provincial People's Government: "Notice on Further Accelerating the Merger and Reorganization of Coal Mining Enterprises and Their Related Issues" (Jin ZhengFa (2009) No. 10).

${ }^{15}$ In fact, in order to complete the task assigned by the provincial government, prefectural governments imposed greater pressure on county (city, district) governments. On August 23, 2009, the Jincheng Municipal Government issued the Notice on "Accelerating the Merger and Reorganization and Reorganization of Coal Mines" (Jin Municipal Office (2009) No. 112), demanding that governments of all counties (cities and districts) must guarantee completion of all the coal mine mergers and reorganizations, and for all merger agreements to be signed before the 31st of August [2009]. For coal mines that had still not signed the merger agreement by August 31, the relevant counties (cities and districts) must suspend their production. The "notice" severely warned county (city, district) governments as well as the mine owners: county (city, district) governments and coal mining enterprises must be determined to overcome the waitand-see tendency, not to have any fantasy and hope about whether the provincial government will alter its decision.... waiting-and-seeing will only bring greater cost. For the counties that cannot complete the merger and reorganization task within the specified time all failing county leaders will be held responsible.

${ }^{16}$ See "Notice on Further Accelerating the Merger and Reorganization of Coal Mines" by the General Office of the People's Government of Xinzhou, Xinzhengfa (2009) No. 158, August 24, 2009. 
${ }^{17}$ The owners of the merging mines were cautious when looking for media to voice their complaints and were always afraid of revealing their personal identities. One private coal miner who accepted an interview with a reporter had to call the reporter after the interview saying that "[I] am being watched by the government, leaving for a few days" (Cao and Li 2009).

${ }^{18}$ Zhejiang Capital Investment Promotion Association, Zhejiang Hang Tianxin Law Firm: "Citizens' Suggestions on Requesting the Examination of the Legality and Rationale of the Regulatory Documents [(Jin ZhengFa, [2009] No. 10) and (Jin ZhengFa, [2008] No. 23)] of Shanxi Provincial Government", November 9, 2009.

${ }^{19}$ Wenzhou TV broadcast an interview, featuring a Wenzhou coal mine boss protesting about the merger and reorganization policy of Shanxi Province. Subsequently, he received open criticism from a major government official of the Shanxi provincial government, which scared the coal boss who immediately returned to Shanxi and signed the merger and reorganization agreement. The reason the coal boss was this cautious was because his mines were in Shanxi, and if the Shanxi government knew that he had spoken out against the merger policy, he might not receive any compensation at all (cited from Xu 2009).

${ }^{20}$ According to the results of the survey conducted by Zhejiang Zize Law Firm in July 2009, Zhejiang businessmen set up more than 450 coal mines in Shanxi Province and invested more than 50 billion yuan in more than 500 coal mines. The merger and reorganization caused Zhejiang businessmen a loss of 25 billion yuan (see He 2009).

${ }^{21}$ See Liupanshui Municipal People's Government "Opinions on Accelerating the Implementation of Mergers and Acquisitions of Coal Mines," May 2011.

${ }^{22}$ See the General Office of the People's Government of Guizhou "Advices on the Accelerate Instructing of the Implementation of Mergers and Acquisitions of Coal Mines," Guizhou, Qianfubanfa (2011) No. 47.

${ }^{23}$ Based on the authors' survey, among all Jinsha mining coal enterprises in 2011, only one was state-owned, called "Guizhou Lianyun Mining Company", and the rest were private enterprises. Guizhou Lianyun Mining Company was an enterprise owned by SASAC in Lianyungang City, Jiangsu Province. In 2011, the company had nine mines in the city of Bijie (including Jinsha County).

${ }^{24}$ The above information, unless stated otherwise, comes from the authors' survey in Jinsha County from 2014 to 2015.

${ }^{25}$ "Vice Governor Wang Jiangping in the city investigating coal mine enterprises' mergers and acquisitions and safety work," "Bijie Daily" July 13, 2013.

\footnotetext{
Acknowledgements

This study is sponsored by the Centre for Research of Private Economy at Zhejiang University (CRPE) and supported by the Fundamental Research Funds for the Central Universities (Lanzhou University, 17LZUJBWZY008). PhD candidate Wang Ning from the School of Economics at Zhejiang University participated in some of our research work. Dr. Lu Jiankun, Dr. Mo Weiqiao, and other PhD candidates including Zhang Xiaoming, Zhong Pei, Wang Ning, Nie Jing from the School of Economics also joined our regular discussion meetings. In the Academic Conference "Economics and Society" hosted by the Third Sector Research Centre at the ShangHai University of Communication on 8th of May, 2016, professor Liu Shiding from the department of Sociology at Beijing University, and Associated Professor Wang Qingming from the department of sociology at Nankai University etc. provided important critique and questions for our study. We sincerely appreciate all the above contributions. Moreover, we give special thanks to the constructive criticism of anonymous reviewers and their amendment suggestions of our article.
} 
Competing interests

The authors declare that they have no competing interests.

\section{Publisher's Note}

Springer Nature remains neutral with regard to jurisdictional claims in published maps and institutional affiliations.

\section{Author details}

${ }^{1}$ Department of Sociology, Zhejiang University, No.38 Zheda Road, Hangzhou 310008, Zhejiang Province, China.

${ }^{2}$ School of Economics, Lanzhou University, No.222 Tianshui Road, Lanzhou 730000, Gansu Province, China.

Received: 27 May 2017 Accepted: 5 July 2017

Published online: 14 July 2017

\section{References}

Blanchard, Oliver \& Andrew Shleifer 2001, Federalism with and without Political Centralization: China vs. Russia. IMF Staff Papers. 48:171-179.

Cao, Zhenghan. 2008. The Logic of the Social Construction of Property Rights-Comment on Chinese Sociologists' Studies on Property Rights from the Perspective of Game Theory. Sociological Studies 1: 200-216.

Cao, Zhenghan. 2011. The Vertically Decentralized Authoritarianism and the Mechanism of Political Stability in China. Sociological Studies 1: 1-40.

Cao Haidong, Li Tingzhen, 2009, Coal Boss Fought back, Questioned Shanxi Coal Reform Law. Southern Weekend, November 5.

He Xiaochun, 2009, How Much Has Coal Mine Merger and Reorganization Injured Zhejiang Business Capital? Businessmen of Chekiang, October 28.

Institute of Sociology, Chinese Academy of Social Sciences. 2006. Chinese Sociology, vol. 5. Shanghai: Shanghai People's Publishing House.

F Pierre Landry, 2008, Decentralized Authoritarianism: The Communist Party's Control of Local Elites in the Post-Mao Era. New York: Cambridge University Press.

Liu, Shiding. 2003a. Fairness in the Process of Public Choice: Logic and Operation. In Possession, Cognition and Interpersonal Relations, ed. Shiding Liu, 1-31. Beijing: Huaxia Publishing House.

Liu, Shiding. 2003b. The Three Dimensions of the Possession System and the Identification Mechanism of Possession-a Case Study of Township Enterprises. In Possession, Cognitive and Interpersonal Relationships, ed. Shiding Liu, 143-167. Beijing: Huaxia Publishing House.

Maskin, Eric, Yingyi Qian, and Chenggang Xu. 2000. Incentives, Scale Economies and Organization Forms. Review of Economic Studies 67: 359-378.

Montinola, G, Qian Yingyi, and Weingas Berry. 1995. Federalism, Chinese Style: The Political Basis for Economic Success in China. World Politics 48(1): 50-81.

National Coal Mine Safety Supervision Bureau, Coal Information Research Institute: China Coal Industry Yearbook (20082013), Beijing: China Coal Industry Press.

Qian, Yingyi, and Barry Weingast. 1997. Federalism as a Commitment to Preserving Market Incentives. Journal of Economic Perspectives 11(4): 83-92.

Shen, Jing, and Hansheng Wang. 2005. The Practical Logic of Collective Property Rights in Rural Chinese Villages. Sociological Studies 1: 113-148.

Sugden, R. 1989. Spontaneous Order. Journal of Economic Perspectives 3: 85-97.

Xu Linling, 2009, The Fate of Wenzhou Coal Boss. Southern People Weekly, November 24.

Xu, Chenggang. 2011. The Fundamental Institutions of China's Reforms and Development. Journal of Economic Literature 49(4): 1076-1151.

Zhang, Jing. 2003. The Uncertainty of the Rules of Land Use: A Legal Sociological Interpretation Framework. Chinese Social Sciences 1: 113-124.

Zhang, Jing. 2005. Dual Integration Order: An Analysis of Property Disputes. Sociological Studies 3: 1-19.

Zhe, Xiaoye, and Yingying Chen. 2004. How Does Capital Work?-A Sociological Analysis of Capital Initiative in Restructuring. Chinese Social Sciences 4: 147-160.

Zhe, Xiaoye, and Yingying Chen. 2005. How to Define Property Rights? Sociological Studies 4: 1-43.

Zhou, Lian. 2008. Local Government in Transition: Official Incentive and Governance. Shanghai: Gezhi Publishing House, Shanghai People's Publishing House. 